\title{
The relative effectiveness of liquid MHA-FA compared with DL-methionine in broiler chickens - a dose-response experiment
}

\author{
A. Kaszuba ${ }^{1}$, J. Koreleski², S. Świątkiewicz ${ }^{2}$, W. Szczurek ${ }^{2}$ \\ and A. Lemme ${ }^{3}$ \\ ${ }^{1}$ Degussa Polska Ltd., Feed Additives \\ 02-697 Warszawa, Poland \\ ${ }^{2}$ National Research Institute of Animal Production, \\ Department of Animal Nutrition and Feed Science \\ 32-083 Balice, Poland \\ ${ }^{3}$ Degussa AG, Feed Additives, Applied Technology and Technical Service \\ 63457 Hanau, Germany
}

\section{ABSTRACT}

A dose-response experiment with chicken broilers was performed in order to examine the relative effectiveness of liquid methionine-hydroxy analog-free acid (MHA-FA) and DL-methionine (DL-Met). Chickens were fed graded levels of either DL-Met or liquid MHA-FA from 1 to 42 days of age. During the experiment body weight gain (BWG) and feed conversion ratio (FCR) were determined.

Increasing levels of DL-methionine and MHA-FA in the diet significantly improved BWG and FCR. Based on multiple non-linear regression analysis, the relative effectiveness of liquid MHA-FA was 64 and 59\% compared with DL-Met with respect to BWG and FCR, respectively.

KEY WORDS: chickens, DL-methionine, liquid methionine-hydroxy analogue, dose response

\section{INTRODUCTION}

The absorption, metabolism and effectiveness of different commercial methionine sources have been investigated by physiologists and nutritionists for years (Lewis and Baker, 1995; Jansman et al., 2003). The relative effectiveness of liquid hydroxy-4-methylthiobutanoic acid (MHA-FA) compared with DL-methionine (DL-Met) is determined in a simultaneous dose-response assay in which graded

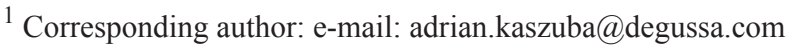


levels of either source are fed to animals. Multi-linear or multi-exponential regression analysis of the trial data allows for an estimation of how much DL-Met is needed to replace liquid MHA-FA in a diet without affecting animal performance. Therefore, relative effectiveness is a relative value that compares the nutritional potential of a nutrient with a defined standard (in this case DL-Met) and thus such estimates can then be taken as a basis for an economical assessment of the products. In broilers, the most commonly used parameters are body weight gain (BWG) and feed conversion ratio (FCR) (Lemme at al., 2002). The objective of the current experiment was to determine the relative effectiveness of liquid MHAFA compared with DL- Met in order to strengthen the conclusions from the abovementioned literature surveys.

\section{MATERIAL AND METHODS}

In total, 550 male day-old broiler chickens (Cobb 550) were randomly allocated to 11 dietary treatments. Birds were housed in brooder cages with 10 broilers per cage. Treatments were replicated five times. Birds received starter diets from day 1 to 21 and grower diets from day 22 to 42 . Mash feeds mainly based on maize, wheat, field beans and soyabean meal were given on an ad libitum basis. The digestible Met + Cys contents of the basal starter and grower diets were 0.54 and $0.53 \%$ and thus clearly deficient, which is a requirement for dose- response experiments. Methionine sources were supplemented on equimolar levels $(0.03,0.06$, $0.10,0.14,0.20 \%$ of diet) assuming a content of active substance of 88 and $99 \%$ for liquid MHA-FA and DL-Met. With increasing inclusion levels, steps increased in order to well describe particularly the sensitive part of the response curves with a sufficient number of data points as suggested by Pack and Beste (1992). Feed analyses for DL-Met and liquid MHA-FA confirmed successful feed production. Body weight and feed intakes were recorded on days 1 (only weight), 21 and 42 and subsequently BWG and FCR were calculated. FCR data were corrected for mortality. The results from the above dose-response experiment were analysed by multiple exponential regression as described by Lemme et al. (2002).

\section{RESULTS}

In general, the broilers performed well with low mortality (4.2\%). Compared with the basal diet, BWG and FCR was significantly improved, by 17 and 14\%, at the highest supplementation levels. Multi-exponential regression analysis revealed a relative effectiveness of 64 (BWG) and 59\% (FCR) for liquid MHA-FA compared with DL-Met on a product (as is, weight-to-weight) basis (Figure 1). 

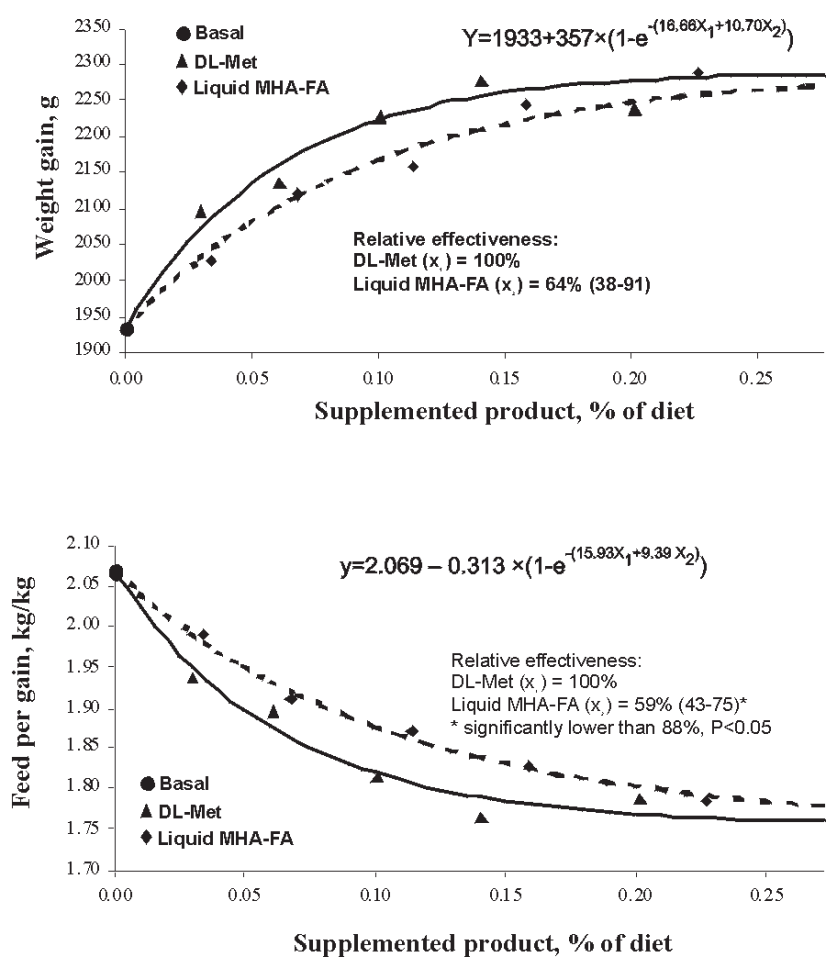

Figure 1. Relative effectiveness of liquid MHA-FA compared with DL-Met for weight gain (top) and feed conversion ratio (bottom) determined on product (weight-to-weight) basis using 1-42-day-old male broilers

\section{DISCUSSION}

The responses of male 1-42-day-old broilers indicated that the basal diet was clearly deficient in dietary methionine (and cysteine) as graded levels of both products resulted in substantial improvements in performance. Moreover, data points well described the sensitive part of the response curve for both products (Figure 1). Thus, the requirements for a simultaneous regression analysis were met. Although supplemented on a molar basis, regression analysis was performed on a product basis to make the result directly applicable to practical feed formulation (on a molar basis, relative effectiveness was 72 and $66 \%$ for BWG and FCR). The determined relative efficacy figures of the current experiment are in good agreement with the outcome of the studies by Lewis and Baker (1995) and Jansman et al. (2003). 


\section{CONCLUSIONS}

The responses of male 1-42-day-old broilers in the presented dose-response trial were appropriate for the determination of the relative effectiveness of Met sources and respective data analysis suggested that 100 parts of liquid MHA-FA in a diet can be replaced by 64 parts or 59 parts DL-Met without affecting body weight gain or feed conversion ratio.

\section{REFERENCES}

Jansman A.J.M., Kan C.A., Wiegenga J., 2003. Comparison of the biological efficacy of DLmethionine and hydroxy-4-methylthiobutanoic acid (HMB) in pigs and poultry. Centraal Veevoederbureau (CVB) Documentation Report 29, CVB, Lelystad (The Netherlands)

Lewis A.J., Baker D., 1995. Bioavailability of D-amino acids and DL-hydroxy-methionine. In: C.B. Ammerman, D.H. Baker, A.J. Lewis (Editors). Bioavailability of Nutrients for Animals: Amino Acids, Minerals and Vitamins. Academic Press, San Diego, CA, pp. 67-81

Lemme A., Höhler D., Brennan J., Mannion P., 2002. Relative effectiveness of methionine hydroxy analog compared to DL-methionine in broiler chickens. Poultry Sci. 81, 838-845

Pack M., Beste R., 1992. How to evaluate different sources of the same nutrient? World Poultry 8 (7), 17-19

\section{STRESZCZENIE}

Relatywna efektywność płynnego MHA-FA w porównaniu z DL-metioniną w żywieniu kurcząt brojlerów

Doświadczenie przeprowadzono na 550 kurczętach brojlerach w celu określenia efektywności płynnego hydroksyanalogu metioniny (MHA-FA) i DL-metioniny (DL-Met). Od 1 do 42 dnia życia kurczęta żywiono podstawową mieszanką paszową z rosnącym poziomem DL-Met oraz MHA-FA, oznaczając przyrosty masy ciała (BWG) i wykorzystanie paszy (FCR). Przy zwiększającym się dodatku DL-Met i MHA-FA do paszy znacząco poprawiły się BWG i FCR. W oparciu o wielokrotną nieliniową analizę regresji efektywność płynnego MHA-FA wyniosła 64 i 59\% w porównaniu z DL-Met, odpowiednio dla BWR i FCR. 